\title{
GEOMETRI FRAKTAL DAN TRANSFORMASI GEOMETRI SEBAGAI DASAR PENGEMBANGAN MOTIF BATIK SEKAR JAGAD
}

\author{
Linda Dwi Fenti Anggraini \\ SMK 17 Agustus 1945 Muncar Banyuwangi \\ lindadwifentianggraini@gmail.com
}

\begin{abstract}
Abstrak
Batik adalah bagian dari kebudayaan yang telah menjadi keseharian masyarakat Indonesia.Setiap motif yang digambarkan pada kain biasanya memiliki filosofi atau makna-makna tertentu yang dipengaruhi oleh kondisi disekitar pembuat batik, salah satunya adalah motif batik SekarJagad. Pengembangan motif batik dapat dilakukan dengan berbagai cara, salah satunya dengan menggunakan pola-pola geometri fraktal. Pengembangan tersebut dapat dipadukan dengan perkembangan teknologi informasi sehingga diperoleh variasi yang lebih beragam.

Penelitian ini merupakan penelitian terapan yang bertujuan mengembangkan motif batik sekar jagad dengan pola-pola geometri fraktal berbantuan transformasi geometri serta aplikasi Maple 13 dan Corel Draw. Pola-pola geometri fraktal yang digunakan (segitiga Sierpinski, kurva Hilbert/Peano, Koch Snowflake, dan himpunan Mandelbrot) yang telah dibangkitkan sampai beberapa iterasi kemudian ditransformasikan, dan selanjutnya disatukan dengan menggunakan aplikasi sehingga terbentuk motif batik sekar jagad.
\end{abstract}

Kata kunci: Geometri Fraktal. Transformasi Geometri, Aplikasi Maple 13, Motif Batik Sekar Jagad

\section{PENDAHULUAN}

Geometri adalah salah satu cabang dari ilmu matematika yang memuat konsep-konsep abstrak dan tidak mudah dipahami. Dalam geometri dipelajari hubungan antara titik-titik, garis-garis, sudut-sudut, bidang-bidang, serta bangun datar dan bangun ruang/solid (Susanah \& Hartono, 2009:1). Hubungan-hubungan yang ada dalam geometri banyak memunculkan konsep-konsep bernilai seni tinggi yang dapat digunakan dalam kehidupan sehari-hari, seperti dalam bidang arsitektur, seni rupa, seni lukis, dan lain-lain.

Geometri melahirkan banyak produk-produk seni yang indah diantaranya adalah batik. Batik adalah bagian dari kebudayaan yang telah menjadi keseharian masyarakat Indonesia. Sejak jaman berdirinya kerajaan-kerajaan di Indonesia

1 | TRANSFORMASI - Jurnal Pendidikan Matematika \& Matematika

Vol. 3 No. 1 Edisi Bulan Juni Tahun 2019 ISSN: 2549-1164 
hingga saat ini batik menjadi bagian yang tidak terpisahkan dalam kehidupan sehari-hari masyarakat. Secara fakta, batik adalah warisan budaya asli Indonesia. Namun, kenyataannya perlindungan terhadap warisan budaya oleh warga Indonesia sendiri masih lemah, sehingga Negara tetangga "Malaysia" mengklaim batik sebagai salah satu warisan budaya mereka. Perselisihan dan persengketaan ini akhirnya diselesaikan oleh UNESCO dengan menetapkan batik sebagai salah satu warisan dunia asli Indonesia pada tanggal 2 Oktober 2009 (Tyas, 2013:1). Penetapan tersebut menyebabkan tanggal 2 Oktober diperingati sebagai Hari Batik Nasional.

Batik adalah kerajinan yang memiliki nilai seni yang tinggi dan telah menjadi bagian dari budaya Indonesia. Secara umum batik berkembang di pulau Jawa yang dipengaruhi adanya kerajaan-kerajaan di masa lampau. Batik berasal dari bahasa Jawa "amba" yang berarti menulis dan titik yang jika digabungkan dapat diartikan sebagai menulis titik-titik pada sebuah kain. Batik juga dapat diartikan sebagai gambar yang ditulis pada kain dengan mempergunakan malam sebagai media sekaligus penutup kain batik (Tyas, 2013:2). Penggunaan malam sebagai media dalam pembuatan batik menjadikan batik sebagai suatu kerajinan yang istimewa karena proses pembuatan yang dilalui membutuhkan waktu yang cukup lama.

Perkembangan motif batik pada tiap-tiap daerah memunculkan keberagaman sesuai dengan pengaruh lingkungan. Setiap motif yang digambarkan pada kain biasanya memiliki filosofi atau makna-makna tertentu yang dipengaruhi oleh kondisi disekitar pembuat batik. Seperti motif ceplok-grompol pada batik Yogyakarta yang memiliki arti berkumpul atau bersatu (Yogyakarta, 2014).

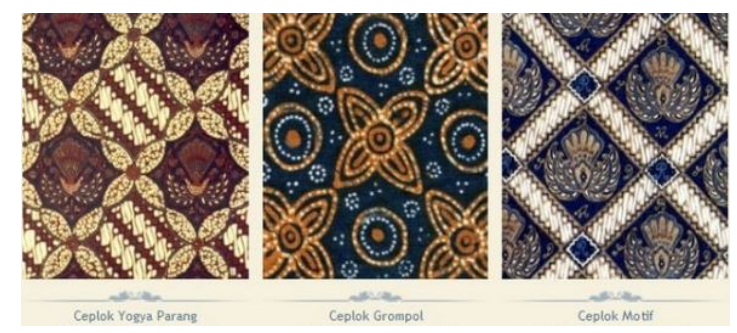

Gambar 1. Motif Ceplok Yogyakarta (Batik Yogyakarta, 2014)

$2 \mid$ TRANSFORMASI - Jurnal Pendidikan Matematika \& Matematika

Vol. 3 No. 1 Edisi Bulan Juni Tahun 2019 ISSN: 2549-1164 
Motif batik ini biasa digunakan dalam prosesi pernikahan oleh kedua mempelai. Filosofinya adalah harapan orang tua akan berkumpulnya semua hal baik seperti: rejeki, kerukunan hidup, kebahagiaan, dan ketentraman untuk kedua mempelai dan keluarga pengantin.

Batik bukan sekedar lukisan yang dituliskan pada kain dengan menggunakan canting. Selain keragaman motif yang memiliki makna didalamnya, batik di Indonesia juga memiliki keragaman bentuk dan warna yang juga memiliki makna tersendiri yang ingin disampaikan melalui kain batik. Tidak hanya kota Yogyakarta dan Surakarta yang dikenal dengan keberagaman batiknya di Indonesia, tetapi banyak kota lain yang juga dikenal memiliki banyak motif batik dengan ciri khas daerah.

Salah satu motif batik yang cukup dikenal saat ini adalah motif batik "Sekar Jagad". Batik Sekar Jagad merupakan suatu motif batik yang memiliki makna keanekaragaman. Dalam satu potong kain batik dengan motif Sekar Jagad terdapat beberapa motif batik lainnya dengan perpaduan warna yang menggambarkan keanekaragaman dalam budaya.
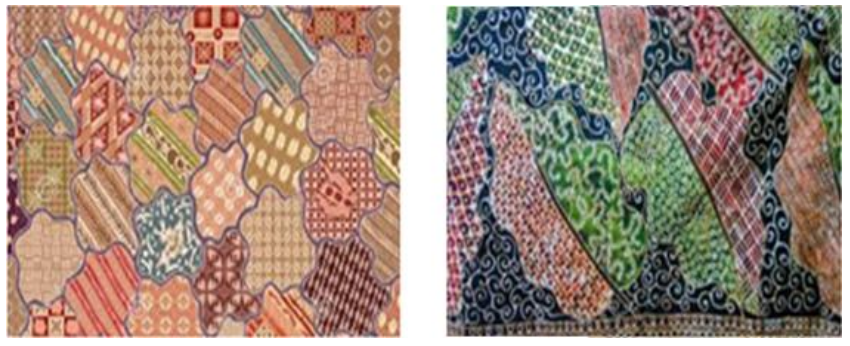

Gambar 2. Beberapa Motif Batik Sekar Jagad

Seiring dengan perkembangan jaman, batik juga mengalami perkembangan mulai dari motif, makna, proses pembuatan, hingga penggunaannya dalam kehidupan sehari-hari. Motif-motif batik dapat dikembangkan dengan berbagai cara, salah satunya dengan menggunakan fraktal. Fraktal adalah bagian geometri yang menjelaskan tentang ketidakteraturan bentuk-bentuk di alam yang tidak dapat digambarkan dengan dimensi geometri umum (geometri Euclid). Fraktal merupakan suatu jenis baru dari geometri yang ditemukan oleh Benoit Mandelbrot pada tahun 1975. Menurut Mandelbrot " $a$ new geometry of nature and 
implemented its use in a number of diverse fields. Its describes many of the irregular and fragmented patterns around us, and leads to full-fledged theories, by identifying a family of shapes I call fractals" (Mandelbrot, 1983:1), yang dapat diterjemahkan sebagai: suatu geometri baru yang diterapkan penggunaannya dalam berbagai bidang yang berbeda. Geometri tersebut menjelaskan berbagai bentuk tidak beraturan dan dapat di fragmentasi (dibagi dalam bagian yang lebih kecil) di sekitar kita, dan mengarahkan pada teori penuh ditumbuhi bulu, dengan mengidentifikasi sekumpulan bentuk yang disebut fraktal.

Perkembangan konsep-konsep fraktal berjalan seiring dengan perkembangan teknologi informasi. Dengan menggunakan fraktal dapat dirancang atau dibuat gambar-gambar tiruan objek alam seperti pohon, gunung, batuan, awan, permukaan bumi atau planet dan lain - lainnya. Perancangan tersebut dilakukan dengan menggunakan transformasi sederhana yang disebut sistem fungsi iterasi (iterated function system) yang disingkat IFS. Menurut Barnsley titik tetap atau atraktor dari sistem fungsi iterasi inilah yang berupa gambar kompleks yang bisa berbentuk objek alam yang mirip sebenarnya.

Perkembangan fraktal memunculkan kemungkinan-kemungkinan baru dalam perkembangan seni kerajinan, salah satunya batik. Berbagai motif batik bisa dapat dihasilkan dari geometri fraktal khususnya dengan fungsi-fungsi yang sudah didefinisikan oleh program atau secara manual user menginputkan (Ulinnuha, 2009:5). Dalam motifnya dapat dihasilkan warna yang beragam dengan cara memasukkan nilai pada masing-masing sistem RGB (Red Green Blue). Kehadiran fraktal dalam seni batik menunjukan bahwa batik merupakan suatu sistem kompleks, hasil interaksi manusia dengan lingkungannya.

Faktor yang berperan besar dalam penerapan fraktal pada batik adalah teknik dekoratif yang berhubungan dengan makna yang terdapat dalam batik, yaitu "isen" atau mengisi motif besar dengan motif kecil yang mirip dengan kesamaan diri pada fraktal. Kombinasi antara batik dengan fraktal yang mempunyai perbedaan konsep dan menerapkan rumus matematika memunculkan motif batik fraktal. Teknologi yang diterapkan pada batik fraktal akan 
menghasilkan desain pola baru yang sangat beragam. Keragaman desain ini dapat dilihat dari grafis, warna, ukuran, sudut, dan perulangan (Yunirahman, 2015:18).

Beberapa penelitian telah dilakukan berkaitan dengan batik fraktal. Salah satu luaran penelitian tersebut adalah dihasilkannya software yang khusus untuk mendesain motif-motif batik fraktal (Yunirahman, 2015:18). Kelebihan batik fraktal adalah dapat didesain menggunakan software dengan lebih efisien dan variatif. Dalam penelitian yang lain telah dikembangkan beberapa batik lokal dengan fraktal, diantaranya batik inovatif yang dihasilkan dengan pola klowongan dan harmonisasi isen-isen dari berbagai ekstrasi pola motif sawat (Gambar 3a), batik hybrid yang dihasilkan dengan pola motif Parang Pedalaman dengan kombinasi fraktal segitiga Sierpinski (Gambar 3b), dan batik fraktal yang dihasilkan dengan pola klowongan dengan zooming (pembesaran) pada bentuk pola fraktal Julia dan harmonisasi isen-isen fraktal Mandelbrot (Gambar 3c).

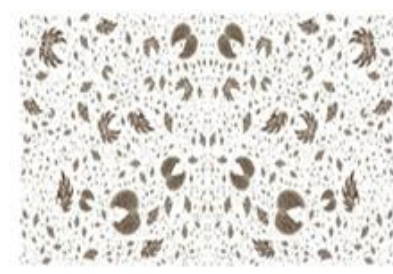

(a)

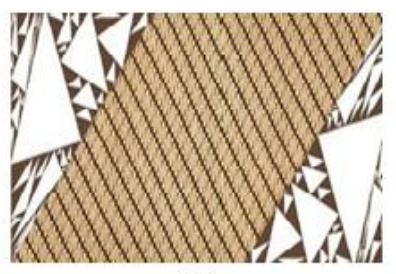

(b)

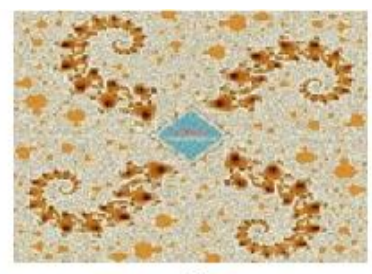

(c)

Gambar 3. Batik Fraktal (Yunirahman, 2015:19)

Proses pembuatan batik fraktal tersebut tidak hanya dapat memanfaatkan aplikasi tertentu yang telah dihasilkan dari penelitian di atas. Terdapat beragam aplikasi lain yang dapat digunakan untuk mengembangkan batik fraktal, salah satunya adalah Maple 13. Maple adalah suatu program aplikasi komputer untuk matematika yang diproduksi oleh Waterloo Maple Inc., Ontario, Canada. Program ini pada awalnya dikembangkan oleh sivitas University of Waterloo, Canada tahun 1988. Maple merupakan suatu Sistem Komputasi Simbolik (Symbolic Computation System) interaktif yang sangat kuat. Program ini telah banyak digunakan oleh kalangan pelajar, pendidik, matematikawan, statistikawan, ilmuwan dan insinyur untuk mengerjakan komputasi numerik dan simbolik (Garvan, 2002:5). 
Selama ini Maple 13 dikenal sebagai suatu aplikasi yang cukup membantu dalam pembelajaran matematika. Aplikasi ini selain dapat digunakan untuk perhitungan, juga dapat digunakan untuk penggambaran bentuk. Pemanfaatan aplikasi untuk pengembangan motif batik diharapkan dapat menjadi inovasi dalam seni batik di Indonesia yang menggunakan obyek-obyek geometri.

Selain pemanfaatan aplikasi, pengembangan motif batik sekar jagad juga dapat dilakukan dengan prinsip-prinsip transformasi geometri. Transformasi Geometri merupakan suatu pemetaan titik pada suatu bidang ke himpunan titik pada bidang yang sama (Yunirahman, 2015:27). Secara umum transformasi geometri memuat prinsip translasi (pergeseran), rotasi (perputaran), refleksi (pencerminan), dan dilatasi (tarikan). Prinsip-prinsip dalam transformasi geometri tersebut bersama-sama dengan aplikasi Maple 13 dapat menjadi dasar yang menarik untuk pengembangan motif batik sekar jagad.

\section{METODE PENELITIAN}

Penelitian ini berjenis Applied Research (PenelitianTerapan), yaitu penelitian yang dilakukan untuk mengkaji kenyataan praktis dalam berbagai bidang (Musfiqon, 2012:54-55). Penelitian terapan dilakukan untuk menerapkan ilmu yang dihasilkan dari penelitian dasar. Sehingga penelitian terapan tidak diarahkan menemukan teori baru, tetapi diarahkan pada pengembangan aplikasi baru dari penelitian yang ada. Penelitian ini mengarah pada penerapan program maple 13 dalam penggambaran pola-pola fraktal untuk mengembangkan motif batik sekar jagad.

Data yang digunakan dalam penelitian ini adalah data sekunder, yaitu data yang tidak langsung diberikan kepada pengumpul data (Sugiyono, 2010:193). Adapun data sekunder yang digunakan dalam penelitian ini adalah pola-pola geometri fraktal (segitiga Sierpinski, kurva Hilbert/Peano, kurva Koch Snowflake, dan himpunan Mandelbrot) yang dibangkitkan sampai iterasi keempat sebagai motif dasar batik Sekar Jagad. 
Adapun langkah-langkah penyelesaian dari penelitian ini adalah sebagai berikut:

1. Pembangkitan pola geometri fraktal yang telah ditentukan (segitiga Sierpinski, kurva Hilbert/Peano, kurva Koch Snowflake, dan himpunan Mandelbrot) sampai iterasi keempat dengan bantuan aplikasi Maple 13.

2. Penggabungan pola geometri fraktal yang telah dibangkitkan dengan menggunakan transformasi geometri. Transformasi geometri yang digunakan yaitu translasi, dilatasi, refleksi, dan rotasi.

3. Pembuatan motif batik Sekar Jagad dengan penggabungan pola geometri fraktal.

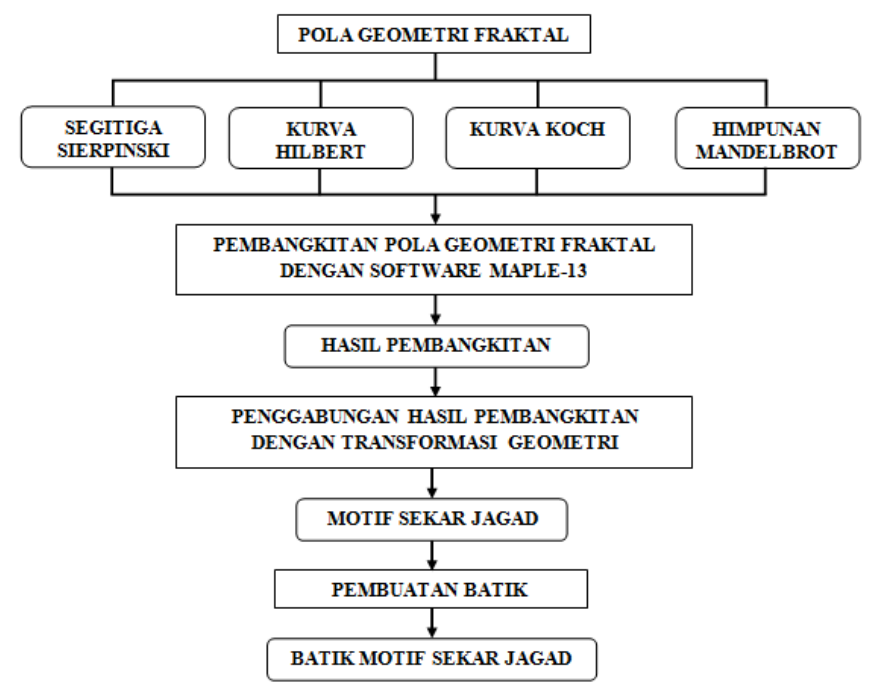

Gambar 4. Diagram Alur Penelitian

Analisis data dilakukan dengan menggunakan analisis kualitatif. Analisis data kualitatif merupakan analisis yang didasarkan pada adanya hubungan semantik antar masalah penelitian. Analisis kualitatif dilaksanakan dengan tujuan agar peneliti mendapatkan makna data untuk menjawab masalah penelitian (Musfiqon, 2012:153). Dalam penelitian ini analisis data dilakukan untuk menganalisis kesesuaian antara rancangan penelitian dengan hasil yang diperoleh. 


\section{HASIL DAN PEMBAHASAN}

Hasil penelitian ini memuat proses pembangkitan, penggabungan pola fraktal yang telah dibangkitkan, dan pembuatan motif batik sekar jagad.

1. Proses Pembangkitan

Proses pembangkitan pada pola geometri fraktal dilakukan dengan berbantuan aplikasi maple 13. Pola-pola yang dibangkitkan adalah Segitiga Sierpinski, Kurva Hilbert, Kurva Koch Snowflake, dan Himpunan Mandelbrot. Pembangkitan Segitiga Sierpinski, Kurva Hilbert, dan Kurva Koch Snowflake dilakukan menggunakan rumus iterasi fungsi sistem pada maple 13 sehingga diperoleh beberapa iterasi. Iterasi yang digunakan dalam penelitian ini sampai 3 iterasi.

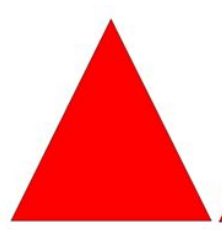

$E_{0}$

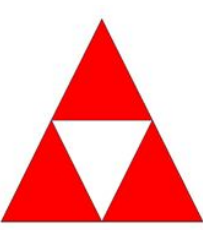

$E_{1}$

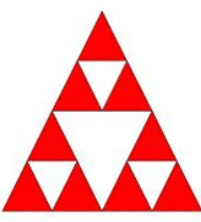

$E_{2}$

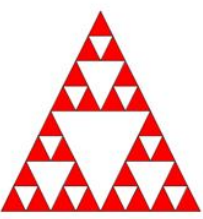

$E_{3}$

Gambar 5. Pembangkitan Segitiga Sierpinski
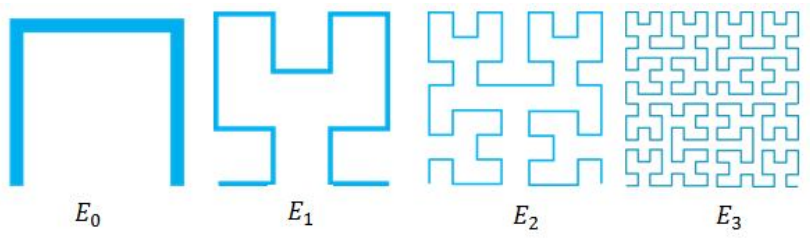

Gambar 6. Pembangkitan Kurva Hilbert

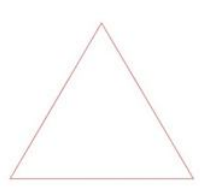

$E_{0}$

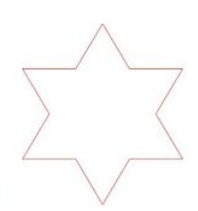

$E_{1}$
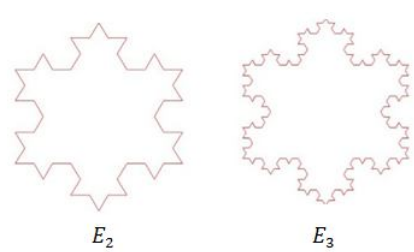

$E_{3}$

Gambar 7. Pembangkitan Koch Snowflake

Proses pembangkitan Himpunan Mandelbrot dilakukan menggunakan bantuan aplikasi maple 13 sehingga menghasilkan Himpunan Mandelbrot 100 iterasi. 


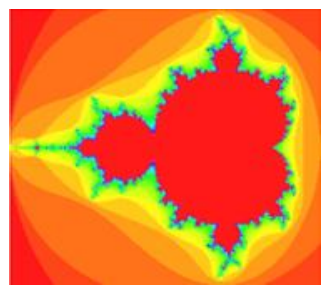

\section{Gambar 8. Pembangkitan Himpunan Mandelbrot}

2. Proses Penggabungan Pola Fraktal yang Telah Dibangkitkan

Hasil pembangkitan pola-pola fraktal yang telah dilakukan dengan aplikasi maple 13, selanjutnya digabungkan dengan menggunakan prinsipprinsip transformasi geometri. Suatu objek dapat diputar mulai dari $1^{0}-$ $360^{\circ}$ dengan menggunakan transformasi geometri yang disebut dengan rotasi. Himpunan Mandelbrot $A$ dapat dirotasi sebesar $15^{\circ}$ berlawanan arah jarum jam. Hasil translasi tersebut akan menghasilkan Himpunan Mandelbrot $B$.

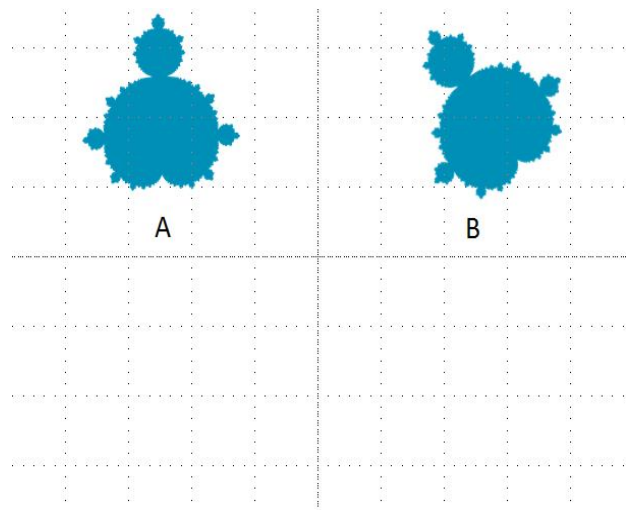

Gambar 9. Rotasi Himpunan Mandelbrot

Refleksi merupakan suatu transformasi yang digunakan untuk mencerminkan suatu objek. Jika Segitiga Sierpinski $A$ sebanyak tiga iterasi direfleksikan terhadap sumbu $Y$ dan sumbu $X$, maka hasil refleksi tersebut akan menghasilkan Segitiga Sierpinski $B$. 


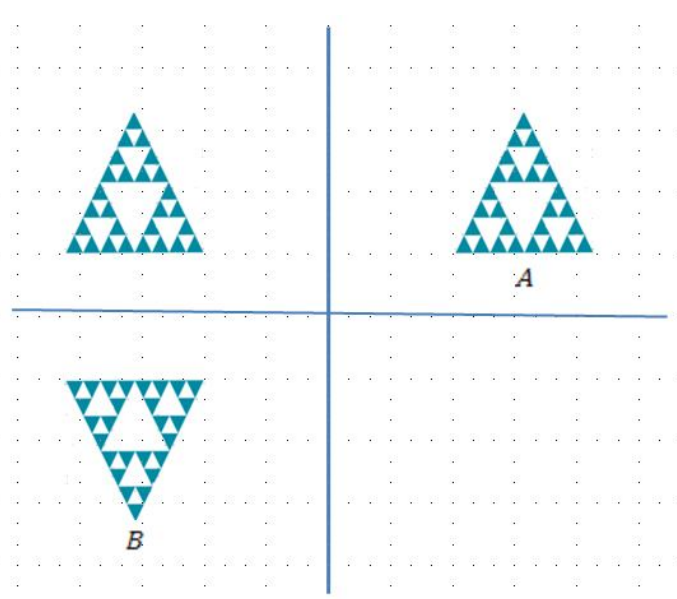

Gambar 10. Refleksi Segitiga Sierpinski

Transformasi lain yang dapat digunakan untuk memperbesar atau memperkecil suatu objek disebut dilatasi. Diberikan Kurva Hilbert $A$ sebanyak tiga iterasi yang memiliki beberapa segmen akan didilatasi/diperbesar sebanyak 2 kali. Hasil dilatasi tersebut akan menghasilkan Kurva Hilbert $B$.

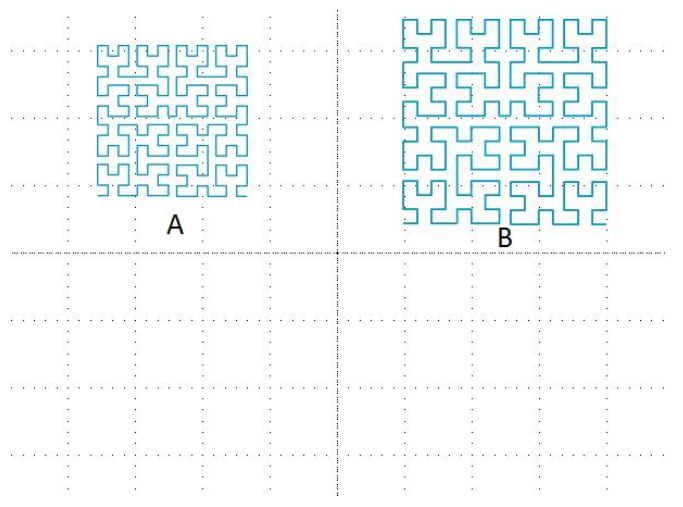

\section{Gambar 11. Dilatasi Kurva Hilbert}

Translasi adalah salah satu bentuk transformasi untuk menggeser suatu objek. Pola fraktal yang melalui proses translasi adalah Koch Snowflake, Himpunan Mandelbrot, dan Segitiga Sierspinski. Koch Snowflake A sebanyak tiga iterasi selanjutnya akan ditranslasi menghasilkan Koch Snowflake $B$. 


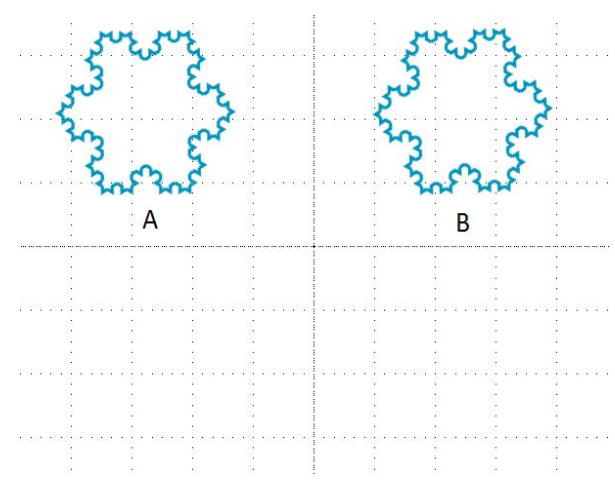

\section{Gambar 12. Translasi Kurva Koch Snowflake}

Himpunan Mandelbrot $A$ yang telah dilakukan rotasi sebesar $15^{0}$ berlawanan arah jarum jam selanjutnya akan ditranslasi sehingga menghasilkan Himpunan Mandelbrot $B$.

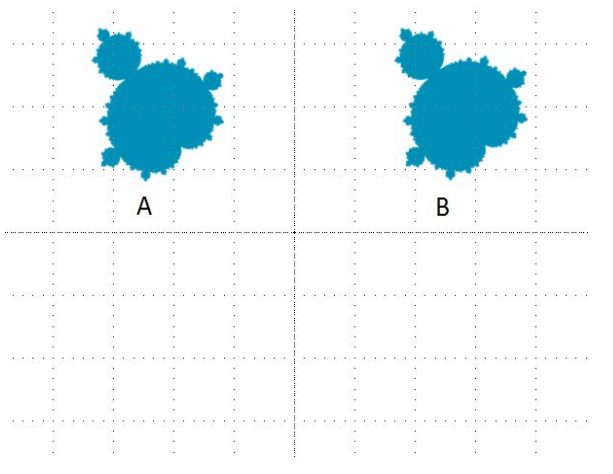

\section{Gambar 13. Translasi Himpunan Mandelbrot}

Segitiga Sierpinski $A$ sebanyak tiga iterasi yang telah direfleksikan terhadap sumbu $Y$ dan sumbu $X$ selanjutnya ditranslasi sehingga menghasilkan Segitiga Sierpinski $B$.

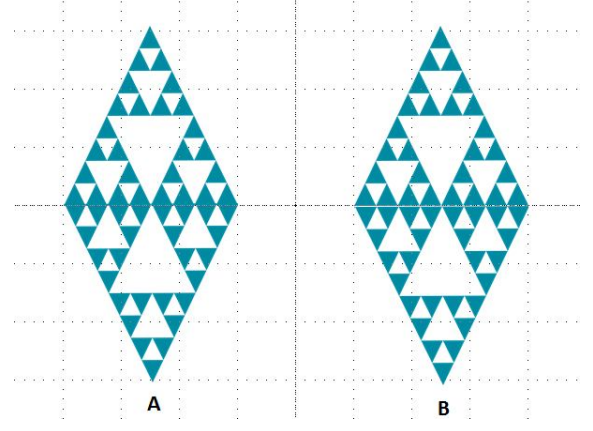

Gambar 14. Translasi Segitiga Sierpinski

11 TRANSFORMASI - Jurnal Pendidikan Matematika \& Matematika Vol. 3 No. 1 Edisi Bulan Juni Tahun 2019 ISSN: 2549-1164 
3. Proses Pembuatan Motif Batik Sekar Jagad

Proses pembuatan desain motif batik fraktal yang telah melalui proses transformasi selanjutnya dilakukan dengan bantuan aplikasi corel draw. Segitiga Sierpinski yang telah refleksikan kemudian ditranslasi sehingga membentuk motif batik segitiga Sierpinski, diletakkan disebelah kiri bawah pada motif batik sekar jagad. Kurva Hilbert yang telah melalui proses dilatasi sehingga membentuk motif batik kurva Hilbert diletakkan disebelah kanan bawah pada motif sekar jagad.
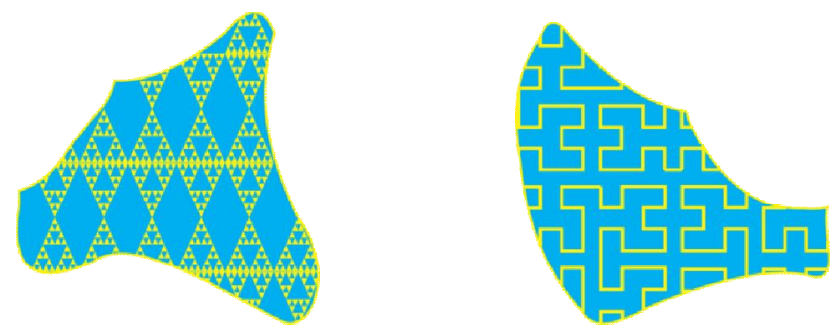

\section{Gambar 15. Motif Batik Segitiga Sierpinski dan Kurva Hilbert}

Koch Snowflake yang telah ditranslasi sehingga membentuk motif batik Koch Snowflake selanjutnya diletakkan disebelah kanan atas pada motif batik sekar jagad. Himpunan Mandelbrot yang telah dirotasi kemudian ditranslasi sehingga mendapatkan motif batik himpunan Mandelbrot selanjutnya diletakkan disebelah kiri atas pada motif batik sekar jagad.
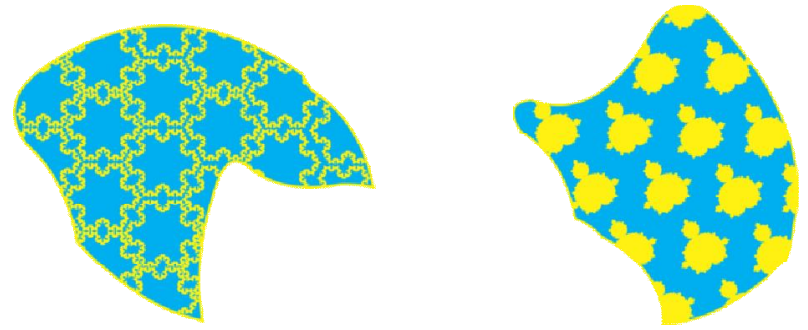

\section{Gambar 16. Motif Batik Koch Snowflake dan Himpunan Mandelbrot}

Sebagai pelengkap yang menunjukkan ciri khas Banyuwangi, diletakkan motif batik Gajah Oling sebagai kombinasi pada bagian tengah pada motif batik sekar jagad. 


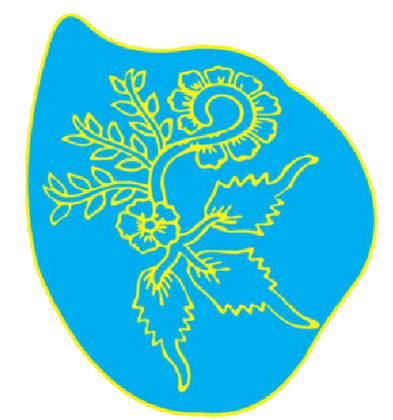

\section{Gambar 17. Motif Batik Gajah Oling}

Pembentukan motif batik fraktal menggunakan Segitiga Sierpinski, Kurva Hilbert, Kurva Koch Snowflake, Himpunan Mandelbrot, dan Gajah Oling selanjutnya disatukan dengan menggunakan aplikasi Corel Draw sehingga terbentuk pola batik motif sekar jagad.
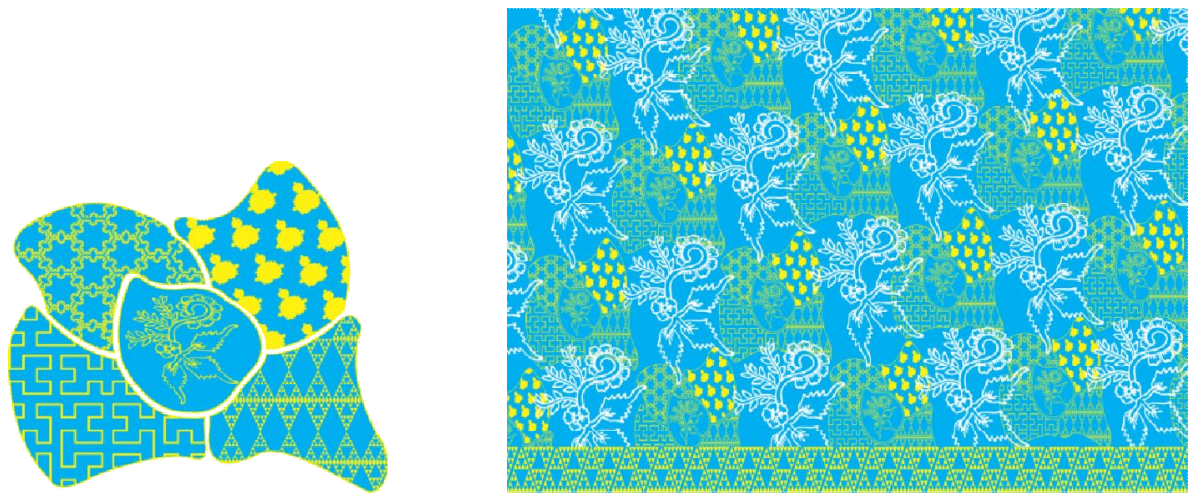

\section{Gambar 18. Modelisasi dan Implementasi Pola-pola Geometri Fraktal}

\section{KESIMPULAN DAN SARAN}

Berdasarkan hasil penelitian dan pembahasannya dapat disimpulkan bahwa geometri fraktal dan transformasi geometri dapat diterapkan dalam pengembangan motif batik baru. Pengembangan dapat dilakukan dengan bantuan aplikasi-aplikasi yang ada sesuai dengan karakteristiknya masing-masing. Hasil pengembangan ini selain dapat digunakan sebagai pembelajaran penerapan matematika dalam kehidupan sehari-hari, juga untuk memberikan pemahaman bahwa matematika bukan hanya suatu materi tanpa makna yang dipelajari di Sekolah.

Penelitian ini hanya menggunakan beberapa pola fraktal dan satu motif batik 
Banyuwangi sebagai penciri kekhasan. Pola-pola fraktal dan motif batik Banyuwangi yang lain dapat digunakan untuk pengembangan penelitian berikutnya. Selain itu aplikasi-aplikasi pendukung yang lain juga dapat digunakan sesuai dengan karakteristik pengembangan motifnya.

\section{REFERENSI}

Garvan, F. (2002). The Maple Book. Boca Raton London New York Washington, DC: A CRC Press Company.

Mandelbrot, B. B. (1983). The Fractal geometry of Nature. New York: W. H. Freeman and Company.

Musfiqon. (2012). Metodologi Penelitian Pendidikan. Jakarta: PT. Prestasi Pustakarya.

Sugiyono. (2010). Metode Penelitian Pendidikan. Bandung: Alfabeta.

Susanah, \& Hartono. (2009). Geometri. Surabaya: Unesa University Press.

Tyas, F. Y. (2013). Analisis Semiotika Motif Batik Khas Samarinda. eJournal Ilmu Komunikasi, Volume 1 Nomor 4, 328-339.

Ulinnuha, M. J. (2009). Perancangan Software Batik Berbasis Geometri Fraktal. Seminar Nasional Matematika dan Pendidikan Matematika. Yogyakarta: Jurusan Pendidikan Matematika FMIPA UNY.

Yogyakarta, B. (2014, Oktober 30). Batik Tulis with Highest Quality. Retrieved April 21, 2017, from Batik Yogyakarta: http://batik-tulis-com/blog/batikyogyakarta

Yunirahman, A. B. (2015). Penggabungan Geometri fraktal Dengan Batik Labako. Jember: Universitas Jember FMIPA (Skripsi Tidak dipublikasikan). 